\title{
Characterization of Youth Agricultural Projects in Limpopo Province of South Africa
}

\author{
Lebohang M. Maele ${ }^{1}$, Azwihangwisi E. Nesamvuni ${ }^{2}$, Khathutshelo A. Tshikolomo ${ }^{3}$, David B. Afful ${ }^{1}$ \\ \& David Norris ${ }^{4}$ \\ ${ }^{1}$ Centre for Rural Community Empowerment, University of Limpopo, South Africa \\ ${ }^{2}$ Office of the Registrar, University of Venda, South Africa \\ ${ }^{3}$ Limpopo Department of Agriculture, South Africa \\ ${ }^{4}$ School of Agricultural and Environmental Sciences, University of Limpopo, South Africa \\ Correspondence: Khathutshelo A. Tshikolomo, Limpopo Department of Agriculture, Private Bag X9487, \\ Polokwane, South Africa. Tel: 27-(0)-15-294-3350. Email: tshikolomo@gmail.com
}

Received: March 25, 2015 Accepted: April 23, 2015 Online Published: June 15, 2015

doi:10.5539/jas.v7n7p42 URL: http://dx.doi.org/10.5539/jas.v7n7p42

\begin{abstract}
The sustainability of agriculture is dependent on the characterization of project participants. The study investigated selected characteristics of participants in youth agriculture projects and constraints faced and proposed strategies for increased project productivity. Three in four (74\%) of the projects were male owned and half $(50 \%)$ of the owners only had primary education. As for project members, $53.8 \%$ were females with $59.3 \%$ of them in mixed vegetable and field crop projects. The project members were youthful with $84.4 \%$ aged $18-35$ (25.3\% were $18-25$ years old, $25.3 \%$ were $26-30$ and $33.8 \%$ were $31-35)$. Four in five (78.2\%) project members were permanently employed. The projects had constraints that reduced their productivity, and those were mainly: (1) weak relationships with other stakeholders resulting in limited access to information, (2) lack of access to funding, and (3) poor land tenure. To improve productivity: (a) youth projects should be encouraged to form (or be part of) cooperatives, (b) initiatives such as NYDA and Mafisa should be strengthened to be more effective in servicing the youth projects, and (c) traditional authorities should establish committees with clear mandate and guidelines for improved land allocation. Strategies to improve productivity of youth projects should consider the described characteristics of participants in terms of gender, age, education and employment status.
\end{abstract}

Keywords: characterization, youths, agricultural projects, Limpopo Province, constraints

\section{Introduction}

Though agriculture has been identified as one of the pillars for economic development for most developing countries; youth participation in the sector is still a great challenge. Agriculture continues to be a significant employer in the Limpopo Province of South Africa. The agricultural sector has the potential to contribute towards alleviation of poverty in rural areas of the province. According to Office of the Premier [OTP] (2009), agriculture remains a key strategic driver for economic growth and rural development and is a major absorbent of labour.

Russell (2001) indicated that the involvement of youths in agricultural production has declined in recent years, especially in rural areas. The poor involvement of youths in agriculture could largely be due to negative perceptions towards the sector. Agriculture is seen as either a dirty job, a poor man's job or a non-income generating job. Observations are that these negative perceptions held by youths towards agriculture tend to lead to a problem of lack of succession. Cook (1996) argued that the future of agriculture may be bleak if production was left in the hands of aged subsistence farmers. There is therefore an urgent need for the agricultural sector to attract youths.

According to the World Bank Report (2007), youth participation in the agricultural sector has the potential to promote the implementation of new technologies. The implementation of new technologies leads to an increase in agricultural production and this is enhanced by the youths' ability to understand and use the technologies as compared to their aged counterparts. This study was done with the purpose of characterizing participants in youth agricultural projects and subsequently proposing strategies for increasing their productivity. 


\section{Research Methodology}

\subsection{Study Area}

The study was conducted in Limpopo Province of South Africa and focused on youth agricultural projects supported by the Limpopo Department of Agriculture (LDA). Limpopo as a province is comprised of five districts (Figure 1), namely: (1) Capricorn (yellowish colour), (2) Mopani (greyish), (3) Vhembe (bluish), (4) Waterberg (greenish) and (5) Sekhukhune District (pinkish) with a total of 25 local municipalities within the five districts. The Province lies at the far north of the Republic of South Africa and is one of the provinces dominated by rural communities.

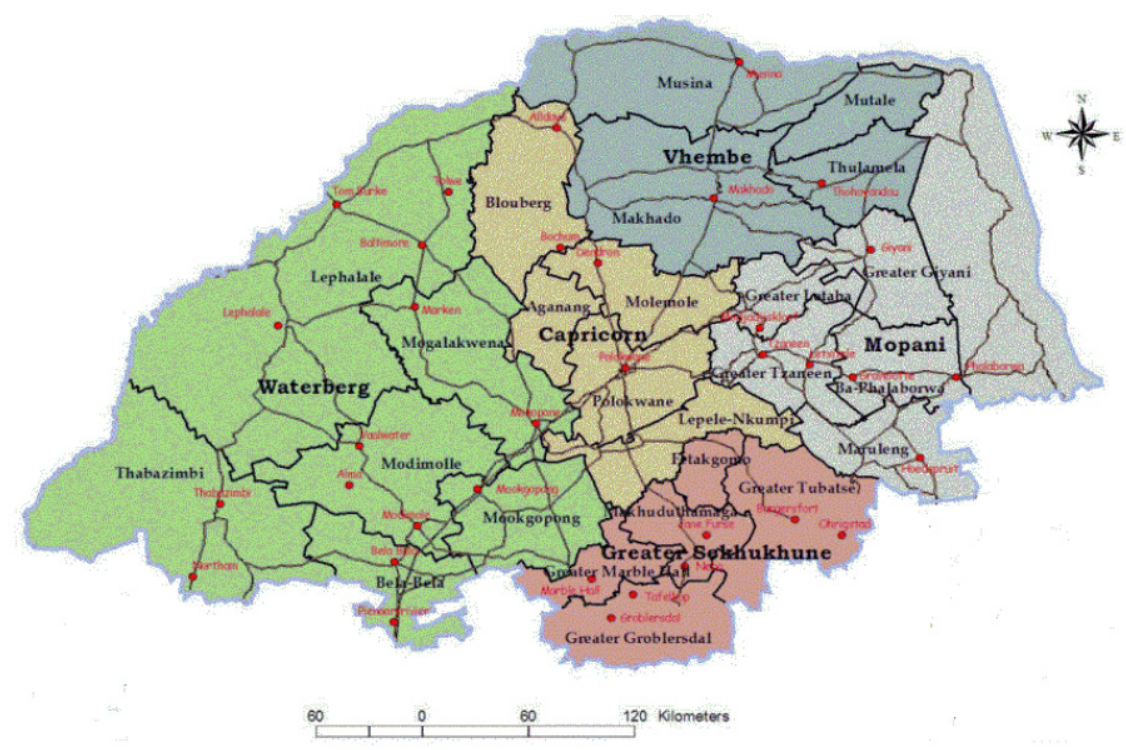

Figure 1. Map of Limpopo Province showing the five district and 25 local municipalities, road infrastructure and the main towns

Although Limpopo is regarded to be generally rural (OTP, 2009), the province has some established infrastructure such as road network and some towns where the youths participating in agricultural projects could buy production inputs and market their farm produce.

\subsection{Sample Frame and Sampling Procedure}

Selection of a representative sample requires correct determination of sample frames (Tshikolomo, Nesamvuni, Stroebel, \& Walker, 2012). Unless a sample frame is borne in mind, it is impossible to properly judge the representativeness of the selected sample (Welman, Kruger, \& Mitchell, 2005) and the trustworthiness of the obtained results (Leedy \& Ormrod, 2010). The sample frame of the study was rural based youth agricultural projects in the five districts of the province. However, as a result of a variety of challenges, only a few youth agricultural projects were functional. There were a total of 139 functional youth projects distributed in the five districts of the Limpopo province. Two youth projects were sampled per municipality for this study. Sampling was stratified based on hierarchical administrative structures, and those were: (i) district municipalities, (ii) local municipalities, and (iii) the youth agricultural projects. The projects were purposively sampled based on their proximity to the place of residence of enumerators.

The selected sample was comprised of 50 out of the $139(36 \%)$ projects in the 25 local municipalities of Limpopo Province. The representative sample of 50 youth projects was selected from all the 5 districts where 10 were from Capricorn, 10 from Mopani, 10 from Sekhukhune, 8 from Vhembe and 12 from Waterberg. The owners (50 respondents) and all members (228 repondents) of the 50 sampled projects were included in the survey.

\subsection{Data Collection and Analysis}

Data was mainly collected through interviews using a structured questionnaire with both open ended and closed ended questions. The data was collected from the project owners and project members. To augment the sample 
focused interviews, group discussions and consultative workshops were also conducted with different stakeholders and project beneficiaries.

Data collected was analyzed using a Statistical Analysis System (SAS, 2009). Basic statistics were computed to determine frequencies of each major variable. Such variables included gender, age, educational level, and relationships with other stakeholders, access to funding and to land tenure. The priority commodities produced by the projects were field crops, vegetables, poultry and a combination of field crops and vegetable production.

\section{Results and Dissucsions}

Any intervention that is meant to improve youth participation in the agricultural sector should be informed by the status quo regarding youth projects. In order to gain a broader understanding of the status quo, the study (1) characterized participants in youth agricultural projects and (2) investigated the constraints experienced by the projects and proposed remedial strategies.

\subsection{Characterization of Youth Agricultural Project Participants}

The main participants in youth agricultural projects were the owners and other members involved in various project activities.

\subsubsection{Characterization of Youth Agricultural Project Owners}

The youth owners included managers of the agricultural projects and were characterized in terms of gender, age, and educational status.

\section{(a) Gender}

Women generally play a major role in the agricultural sector (Asuamah, 1993) and were reported to dominate agricultural activities in African countries (Ugwumba \& Lamidi, 2011; Ukwuaba \& Inoni, 2012). Of the 50 youth agricultural projects sampled for the study, about three in four (74\%) were male owned (Table 1), and hence men were majority at ownership level.

Table 1. Gender distribution of youth owners of agricultural projects in Limpopo Province

\begin{tabular}{lll}
\hline Gender & Number & Percentage \\
\hline Male & 37 & 74.00 \\
Female & 13 & 26.00 \\
Total & $\mathbf{5 0}$ & $\mathbf{1 0 0 . 0 0}$ \\
\hline
\end{tabular}

The finding that men were majority owners of agricultural projects affirmed Bembridge and Tshikolomo (1998) who revealed that $90 \%$ of fruit growers in the Phaswana area of the Limpopo Province were males. As stated by Bembridge and Tshikolomo (1998), gender has influence on decision making with males responsible for major while females were responsible for relatively minor decisions. Resultantly, male youths in this study dominated as project owners. Females would reportedly dominate decisions on production activities and related technology adoption and efficient use of production resources (Echebiri, Igwe, \& Okwun, 2006). The democratic government promotes women empowerment and their equal participation in socio-economic activities and hence strategies should be sought for their increased participation in youth agricultural projects.

(b) Age

Dagada, Nesamvuni, Van Rooyen, and Tshikolomo (2013) revealed that age plays an important role in the life of a person and determines how an individual behaves. In affirmation, Bembridge, Graven, Hough, and Van Rooyen (2008) indicated that age has an influence on decision making and the physical ability of individuals.

Table 2. Age category of youth owners of agricultural projects in Limpopo Province

\begin{tabular}{lll}
\hline Age Category & Number & Percentage \\
\hline $18-25$ & 20 & 40.00 \\
$26-30$ & 25 & 45.00 \\
$31-35$ & 5 & 15.00 \\
Total & $\mathbf{5 0}$ & $\mathbf{1 0 0 . 0 0}$ \\
\hline
\end{tabular}


The majority (45\%) of youth owners of agricultural projects were 26-30 years of age (Table 2). Some two in five (40\%) of the youth project owners were aged $18-25$ while only $15 \%$ fell under the $31-35$ age category.

(c) Educational Status

According to Dagada et al. (2013), human development is influenced by the level of education. Improvement of human resource capacity is essential to meet the challenges of agricultural production and food security. More years of schooling are associated with higher rates of adoption of new technologies (Olaiton, 1984; Tompson, 2008). It was therefore necessary for this study to investigate the educational status of the respondents.

Table 3. Educational levels of youths owning agricultural projects in Limpopo Province

\begin{tabular}{lll}
\hline Educational level & No of respondents & Respondents \% \\
\hline Tertiary education & 5 & 10.00 \\
Secondary education & 15 & 30.00 \\
Primary education & 25 & 50.00 \\
No response & 5 & 10.00 \\
Total & $\mathbf{5 0}$ & $\mathbf{1 0 0 . 0 0}$ \\
\hline
\end{tabular}

Half $(50 \%)$ of the youth owners of agricultural projects had only primary education while an additional $10 \%$ probably had primary or no education as they did not respond to questions on educational status (Table 3). Only $10 \%$ of the youth owners of agricultural projects had tertiary education. The youths with only primary education together with those who did not even disclose their educational status were about three in five $(60 \%)$ and were the majority.

The youths with only primary education would at best possess very basic literacy skills and would not easily access print agricultural and other information, especially those in languages other than their mother tongue. The youths with low levels of education would also lack numeracy skills and would therefore not be able to determine whether their agricultural businesses are making profit or not.

The prospects for access to information and for success in the agricultural business would likely be higher for the $10 \%$ of the youths who attained tertiary education. Approximately $67 \%$ of individuals with tertiary education qualifications complained that they were under-utilized by the youth agricultural projects. Some $15 \%$ of the youths with tertiary education reportedly took interim responsibilities in agricultural projects while they sought for preferred jobs aligned to their qualifications.

\subsubsection{Characterization of Members of Youth Agricultural Projects}

In addition to gender, age and educational status, members of the youth agricultural projects were also characterized in terms of employment status. The characterization also considered the types of agricultural commodities produced.

\section{(a) Gender}

As was highlighted for owners of youth agricultural projects, the gender of members is also important for increased production. Contrary to the result for project owners, female members were slightly more (average $53.8 \%)$ than their male counterparts $(46.2 \%)$. Different from the result regarding project ownership, women provided more of the work force required by the youth agricultural projects. 


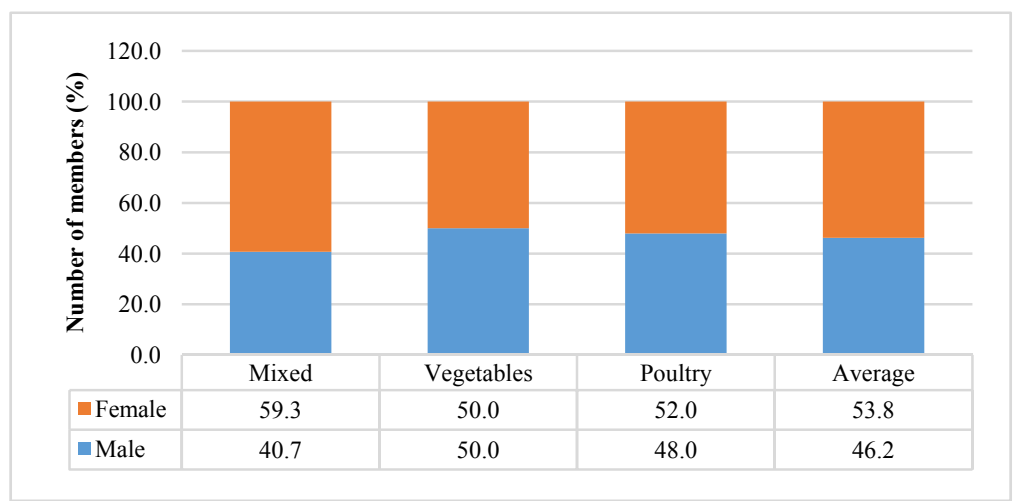

Figure 2. Gender distribution of youth agricultural project members (\%) producing various commodities in Limpopo Province $(\mathrm{N}=228)$

Of the average $53.8 \%$ female youth members in agricultural projects, the majority $(59.3 \%)$ where in projects producing a mix of vegetable and field crops (referred to as 'mixed'), half $(50 \%)$ where in projects producing vegetable only (referred to as 'vegetables') while $52 \%$ were in those producing poultry only (referred to as 'poultry'). Of the male members (46.2\%), only two in five $(40.7 \%)$ were in mixed projects, half were in vegetables and $48 \%$ were in poultry projects (Figure 2). Gender representation of agricultural project members was near equity and both gender groups would have a good share of the economic benefits of the youth enterprises.

(b) Age

The influence of age on the success of an agricultural project cannot be overemphasized. On average, one in four (25.3\%) of youth agricultural project members were $18-25$ years old with the same number $(25.3 \%)$ reported for members 26-30 years of age. The majority of the members (average 33.8\%) were 31-35 years old while only $15.6 \%$ were over 35 years of age (Figure 3 ).

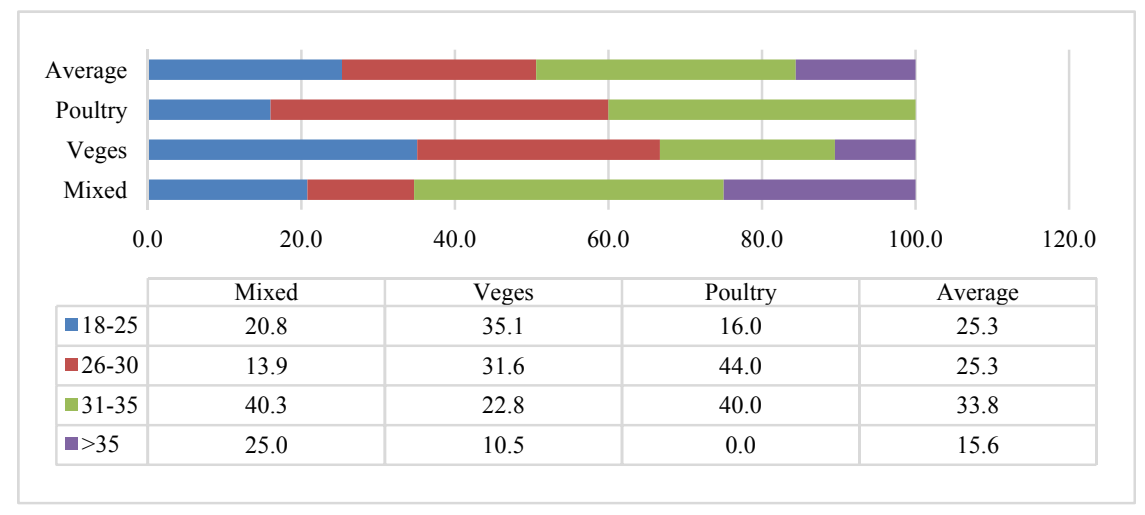

Figure 3. Age distribution (\%) of members of youth agricultural projects producing various commodities in Limpopo Province $(\mathrm{N}=228)$

The majority (40.3\%) of members in mixed farming projects were 31-35. Compared to mixed farming, project members in vegetable production were younger with the majority (35.1\%) within the age groups $18-25$. Project members in poultry production were mainly ( $44 \%$ of members) in the middle age category of 26-30.

Although decisions on commodities produced would mainly be the responsibility of project owners, the members would probably have some influence. The major involvement of relatively older members in mixed crop farming projects suggests that they were concerned about inclusion of field crops such as maize for promotion of household food security. Relatively younger members were probably driven by income generation potential of commodities and favoured vegetables and poultry. Instead of producing the vegetables and poultry 
as single commodities in the projects, the members (and indeed the owners) could be advised to produce in a mixed setup.

\section{(c) Education}

The improvement of human resource capacity is essential to meet the challenges of agricultural production and food security. On average, $27.3 \%$ of the project members had tertiary education, half $(51.2 \%)$ had secondary while one in five $(21.5 \%)$ had primary education (Figure 4$)$.

Only $10 \%$ of project owners had tertiary, $30 \%$ had secondary and about $60 \%$ had primary education (Table 3 ), suggesting that they were generally less educated than project members who would therefore probably have strong influence on production decisions.

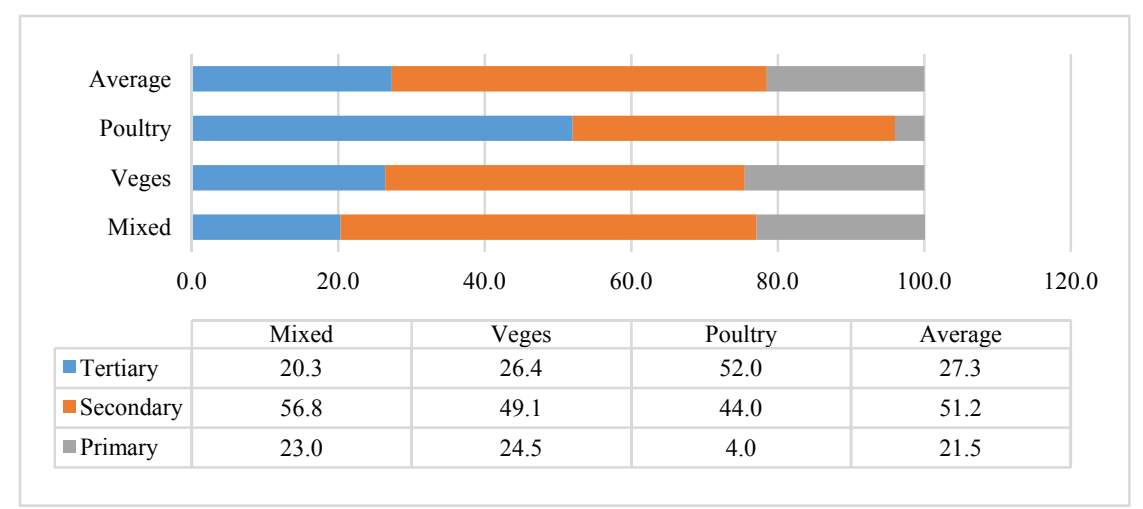

Figure 4. Distribution (\%) of members of youth agricultural projects producing various commodities in Limpopo Province according to level of education $(\mathrm{N}=228)$

The majority of members involved in crop commodities had secondary education where $56.8 \%$ were in mixed crop farming while $49.1 \%$ were in vegetable production. The majority $(52 \%)$ of the members involved in poultry production had tertiary education (Figure 4). The involvement of more members with higher level of education (tertiary) in poultry production was probably a result of the commodity requiring specialized attention. Poultry production requires specialized attention with regards to correct feeding, provision of water (for drinking), vaccination, temperature management and selling time and need specialized knowledge and skills. The crop commodities had relatively more tolerance to production and related inaccuracies and could therefore be practiced by members with relatively less education.

\section{(d) Employment}

The employment status of members of the youth agricultural projects plays an important role in the economic wellbeing of their families. Project members that are permanently employed would be economically well off compared to their temporarily employed counterparts. 


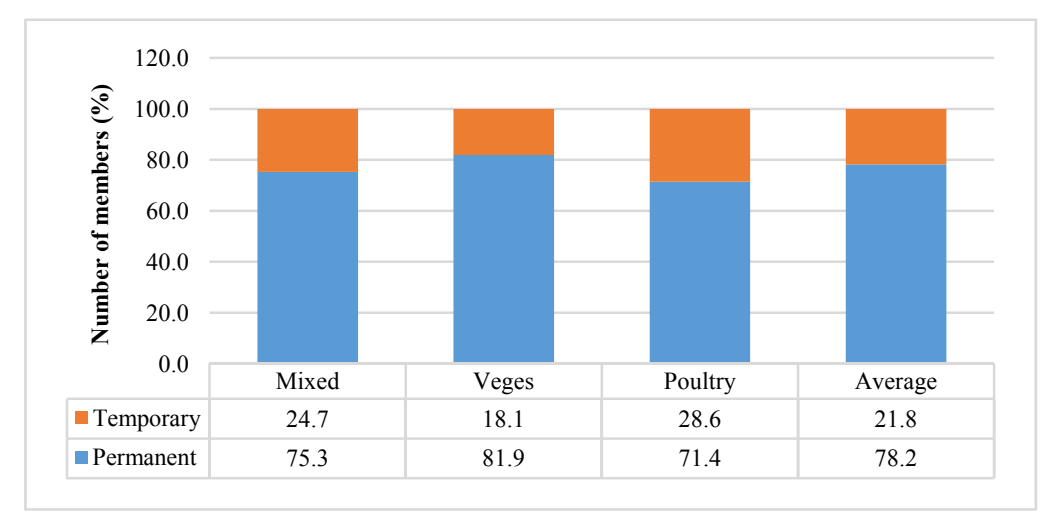

Figure 5. Distribution (\%) of members of youth agricultural projects producing various commodities in Limpopo Province according to type of employment $(\mathrm{N}=228)$

On average, four in five (78.2\%) members of the youth agricultural projects were employed permanently while $21.8 \%$ were temporarily employed. The same trend where the majority of the members were permanently employed occurred for all investigated agricultural commodities. The number of permanently employed project members were three in four $(75.3 \%)$ for mixed crop projects, four in five $(81.9 \%)$ for vegetable projects and seven in ten $(71.4 \%)$ for poultry projects (Figure 5). The fact that youth agricultural projects provided permanent employment to the majority of the members suggests that the projects were important sources of livelihood to those members. Other possible sources of income were government social grants for deserving members.

Project members that were temporarily employed would probably seek alternative employment, create self-employment, or where deserved fall back on social grants for the period when they were not employed. The characterization of participants in youth agricultural projects revealed the project owners to be mostly male, youthful and less educated compared to the project members who were mostly female and relatively more educated. There was need for promotion of gender equity and increased productivity of youth projects and this could be achieved through empowerment of young women to own agricultural projects and provision of training to both owners and members to address identified skills gaps. Some participants, more so project owners would lack basic education and may have to be capacitated through programs such as adult basic education and training (ABET). Participants were generally youthful and would be easy to train.

\subsection{Constraints Faced by Youth Agricultural Projects}

Youth agricultural projects face many constraints, and those include lack of access to information and lack of finance. The constraints have a negative influence on the competitiveness of the youth agriculture projects. Competitiveness was defined as the ability to supply goods and services in the location, form and time they are sought by buyers and at prices that are as good as or better than those of potential suppliers, while earning at least the opportunity cost of returns on resources employed (Freebairn, 1986).

\section{(a) Lack of Strong Relationships and Information Flow}

The existence and strength of relationships between youth agriculture projects and other stakeholders influence the projects' access to information and their productivity. According to Baloyi (2011), increased access to relevant information is positively related to adoption of new technologies and efficient production. The quality of information obtained is influenced by the sources of such information, and the willingness of participants to share information is dependent on the existence of sound relationships among them. Important role players to serve as sources of information to youth agricultural projects included youth cooperatives, Department of Agriculture, banks, NYDA, NGO's and traditional leaders (Figure 6). 


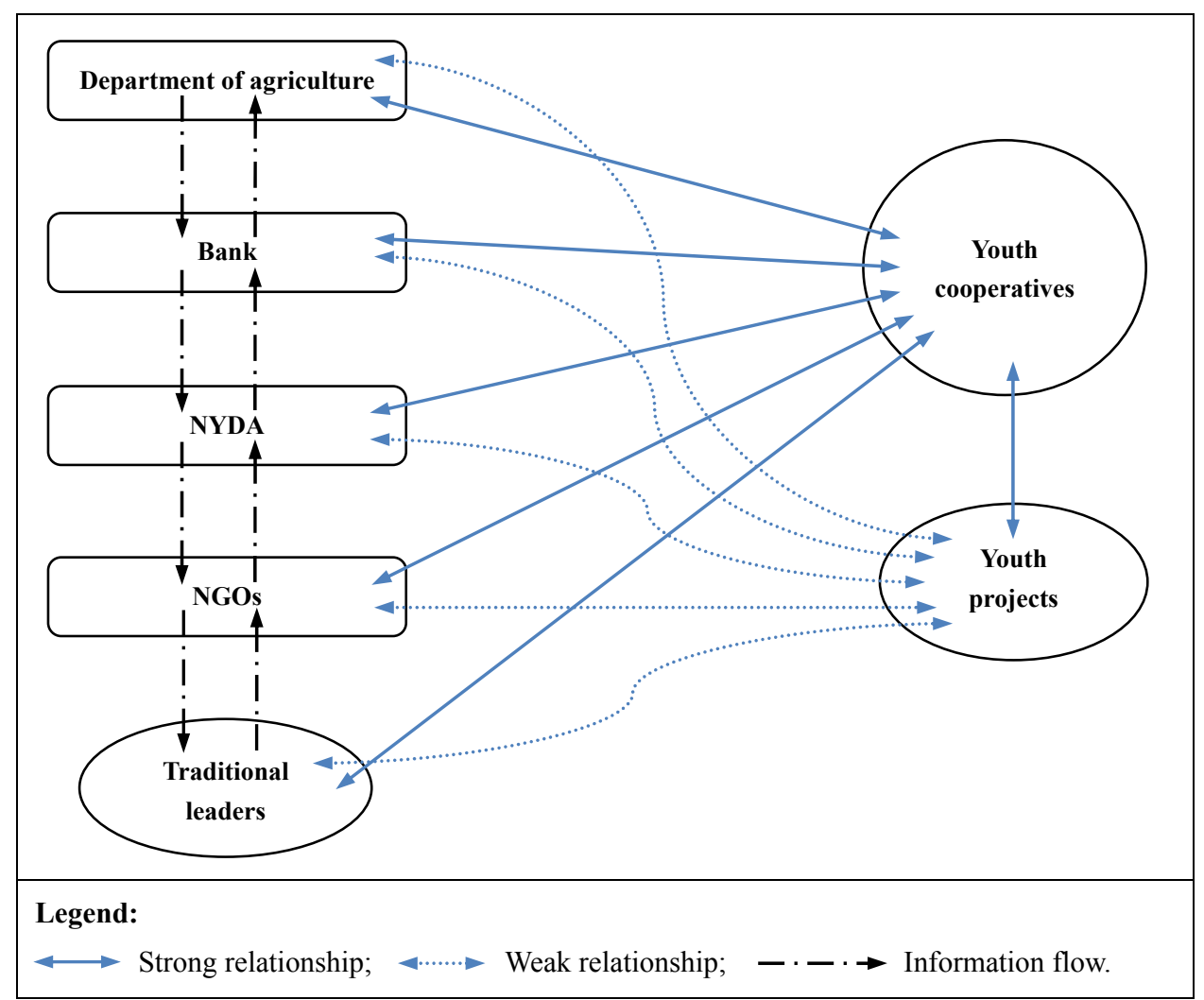

Figure 6. Relationships and information flow between youth agricultural projects and other stakeholders

The youth projects related strongly with youth cooperatives while the relationships with the rest of the stakeholders were reportedly weak. The youth projects and cooperatives were strongly related and would be expected to share information with a lot of ease. The youth cooperatives would therefore likely be the most important source of information to the youth agricultural projects. Weak relationships were reported with the rest of the stakeholders and hence the stakeholders could not serve as important sources of information to the projects. Youth cooperatives reportedly had strong relationships with all the identified stakeholders and would be expected to have received information from all the role players.

The stakeholders other than youth projects and cooperatives also shared some information both directly and indirectly, and this increased the probability for the youth cooperatives to access all the information that each role player possessed. Where the stakeholder might have withheld the information, another role player (with whom it was shared) would have released it to the youth cooperative who would likely share it with the youth projects. The youth cooperatives should therefore be regarded very important for information dissemination to youth projects, and projects that are not members of the cooperatives should where feasible be encouraged to acquire membership.

\section{(b) Funding}

Mpandeli (2006) emphasized the need for farmers to have access to all the required inputs in order to increase production. Government made its contribution through financial support, inputs supply, infrastructure development and capacity development. The funding from government alone cannot provide for all operational needs of youth projects. According to Ezeh, Anyiro and Obioma (2012), access to affordable credit contributes to efficient and effective production. 
Table 4. Distribution of youth agricultural projects according to their access to funding other than government support

\begin{tabular}{lll}
\hline Variable & Frequency & Percentage \\
\hline Additional funding & 8 & 16.0 \\
No additional funding & 28 & 56.0 \\
No response & 14 & 28.0 \\
Total & $\mathbf{5 0}$ & $\mathbf{1 0 0 . 0}$ \\
\hline
\end{tabular}

Other than the prospect for government support, only $16 \%$ of the projects had additional funding from NGOs and other organizations (Table 4). Organizations such as NYDA and programs such as Mafisa were established to address the funding needs of youth projects, however it was reported that these initiatives were ineffective as the funding opportunities remained inaccessible to most rural youth. Increased funding of the rural agricultural youth projects would enable them to improve their on-farm infrastructure and provision of production inputs and would therefore result in increased production. Strategies should therefore be developed to increase youth access to NYDA, Mafisa and other financial support programs.

(c) Access to Land

Access to land has been regarded a major constraint to farmer's productivity and it is linked to historical and political issues. According to Mpandeli (2006), the question of land tenure is relevant in South Africa due to the country's political and historical complexity of land issues, rights and entitlement. Most landholders are unable to invest in infrastructural development of their projects as they do not have secure tenure through title deed or certificate of occupancy or ownership. Secure land tenure is a necessary pre-requisite for adoption of long term sustainability of farming practices (Makhura, 2001).

Only one in four (24\%) of the youth projects investigated had title deeds (Table 5 ), and only a $12 \%$ of the title deeds were registered in the name of the youth project owners. Landholding households that are no longer using their allocated land should make their land available to interested and capable youth seeking access to more land.

Table 5. Distribution of youth agricultural projects according to the tenure under which they acquired land.

\begin{tabular}{lll}
\hline Land tenure & Frequency & Percentage \\
\hline Title deed & 12 & 24.0 \\
Communal \& other & 24 & 48.0 \\
No response & 14 & 28.0 \\
Total & $\mathbf{5 0}$ & $\mathbf{1 0 0 . 0}$ \\
\hline
\end{tabular}

The local chief was responsible for allocation of land and $43.9 \%$ of the study participants felt that the system was not fair at times as there were cases of nepotism and favoritism when allocating land. Some youth projects claim that even though they had the potential and produced good quality products their request for land extension was declined. As stated by Nkuhlu (1985), traditionalism in rural areas tends to hamper agricultural development as it still harbour values, norms and attitudes that contradict rational behaviors in a modern economic sense. In order to improve on land allocation, traditional authorities should establish committees for that purpose with clear mandate and land allocation guidelines.

\section{Conclusion}

The majority (74\%) of youth agricultural projects were male owned and female participation should be promoted. Half $(50 \%)$ of the youth project owners only had primary education. Youth project owners with only primary education would have low levels of literacy and numeracy, would struggle to access and analyze information and would less likely succeed in their farming business.

As for project members, 53.8\% were female with the majority $(59.3 \%)$ in mixed vegetable and field crop projects. Project members were youthful with $25.3 \%$ in the age category of $18-25$ years, same number was $26-30$, up to $33.8 \%$ were $31-35$ while only $15.6 \%$ were over 35 years old. Four in five $(78.2 \%)$ of the project members were permanently employed, and the majority of members across commodity groups belonged to this 
employment category and this made the youth projects an important source of livelihood.

Important constraints faced by youth agricultural projects included (1) weak relationship between youth projects and other stakeholders resulting in limited access to information, (2) lack of access to funding, and (3) poor land tenure. Youth projects had strong relationships with youth cooperatives, and those should be used to disseminate information to the projects. In order to improve productivity, (a) youth projects should be encouraged to form (or be part of) cooperatives, (b) initiatives such as NYDA and Mafisa should be strengthened to be more effective in servicing the youth projects, and (c) traditional authorities should establish committees with clear mandate and guidelines for improved land allocation. Strategies to improve productivity of youth projects should consider the described characteristics of participants in terms of gender, age, education and employment status.

\section{References}

Asuamah, K. Y. (1993). Attitude of extension staff to their work. A research report. UNIBO.

Baloyi, R. (2011). Technical Efficiency in Maize Production by Small-Scale Farmers in Ga-Mothiba, Limpopo Province, South Africa (Unpublished dissertation for Master of Agricultural Management in Agricultural Economics). University of Limpopo, South Africa.

Bembridge, T. J., \& Tshikolomo, K. A. (1998). Communication and decision making among fruit growers in the Phaswana Area of Northern Province. South African Journal of Agricultural Extension, 27, 19-29.

Bembridge, T. J., Graven, E. H., Hough, M. A., \& Van Rooyen, C. J. (2008). An evaluation of the Sheila and Mooifontein projects. Ditsobotla District, Bophuthatswana. Department of Agricultural Extension and Rural Development, University of Fort Hare, Eastern Cape Province, South Africa.

Cook, Y. F. (1996). Summary of paper on Extension and Rural Youth Programme in Selected Countries.

Dagada, M. C., Nesamvuni, A. E., Van Rooyen, J., \& Tshikolomo, K. A. (2013). Operator characterization and acquisition of sold items for Tshakhuma and Khumbe markets of Limpopo Province, South Africa. International Journal of Business and Social Science, 4(8), 181-190.

Echebiri, R. N., Igwe, K. C., \& Okwun, A. K. (2006). Analysis of Technical Efficiency of Urban Broiler Production in Umuahia Metropolis of Abia State (pp. 203-206). Proceedings of the 40th Annual Conference of Agricultural Society of Nigeria, Umudike Umuahia.

Ezeh, C. O., Anyiro, I. O., \& Obioma, N. Q. (2012). Gender Issues on Poverty Alleviation Programmes in Nigeria; The Case of the National Fadama 1 Development Project in Abia State, Nigeria. Agris on-line Papers in Economics and Informatics, 4(3), 15-20.

Freebairn, J. (1986). Implications of wages and industrial policies on competitiveness of Agricultural Expert Industries. Paper presented at the Australian Agricultural Economics Society Policy Forums. Canberra.

Leedy, P. D., \& Ormrod, J. E. (2010). Practical research, planning and design (8th ed.). Pearson Merrill Prentice Hall, New Jersey, USA.

Makhura, T. M. (2001). Overcoming transaction costs barriers to market participation of smallholder farmers in the Northern Province of South Africa (Unpublished Ph.D thesis). University of Pretoria, Pretoria, South Africa.

Mpandeli, N. S. (2006). Coping with climate variability in Limpopo Province (Unpublished Ph.D thesis). University of the Witwatersrand, Johannesburg, South Africa.

Nkuhlu, W. L. (1985). Constraints to the economic development of the Republic of Transkei. Development Southern Africa, 2(4). http://dx.doi.org/10.1080/03768358508439184

Olaiton, S. O. (1984). Agricultural education in the tropics: Methodology for teaching agriculture. Macmillan Intermediate Agricultural Series. New York, United States of America.

Office of the Premier (OTP). (2009). Limpopo Employment Growth and Development Plan. Polokwane, South Africa.

Russell, E. B. (2001). Attracting Youth to Agriculture. University of Illinois, Urbana Champaign.

SAS Institute Inc. (2009). SAS 9.1.2 User's Guide. Cary, NC: SAS Institute Inc.

Tompson, A. R. (2008). Education and development in Africa. MacMillan Education Ltd. London, Britain.

Tshikolomo, K. A., Nesamvuni, A. E., Stroebel, A., \& Walker, S. (2012). Water supply and requirements of households in the Luvuvhu-Letaba Water Management Area of South Africa. International Journal of 
Business and Social Science, 3(3), 37-49.

Ugwumba, F., \& Lamidi, A. I. (2011). Profitability and Economic Efficiency of Poultry Local Government Area of Anambra State. Journal of Poultry Science, 10, 106-109. http://dx.doi.org/10.3923/ijps.2011.106.109

Ukwuaba, I., \& Inoni, O. E. (2012). Resource-Use Efficiency in Small-Holder Broiler Production in Oshimili North Local Government Area, Delta State. Department of Agricultural Economics and Extension, Delta State University, Asaba Campus, Asaba, Delta State, Nigeria. http://dx.doi.org/10.3923/ijps.2012.700.705

Welman, C., Kruger, F., \& Mitchell, B. (2005). Research Methodology (3rd ed.). Oxford University Press, Cape Town, South Africa.

World Bank Report. (2007). Development and the next generation. The World Bank. Washington DC.

\section{Copyrights}

Copyright for this article is retained by the author(s), with first publication rights granted to the journal.

This is an open-access article distributed under the terms and conditions of the Creative Commons Attribution license (http://creativecommons.org/licenses/by/3.0/). 